\title{
Application of Different Vanadium Alloys in Steel
}

\author{
P. Tian, Z.Y. Zhong \\ State Key Laboratory of Electronic Thin Films and \\ Integrated Devices \\ University of Electronic Science and Technology of China \\ Chengdu, China
}

Abstract-The current status of vanadium bearing steel and characteristics of different vanadium alloys were analyzed, the effect of different vanadium alloys on $V$ absorption rate and steel properties was investigated, and the varieties of steel properties and $V / N$ ratio under different nitrogen conditions were discussed. It could be concluded that the ferrovanadium should be used mainly in the steel with strict limits on nitrogen content and the ferrovanadium nitride would be preferred in vanadium-nitrogen strengthened steel. The vanadium-nitrogen strengthening can be enhanced with nitrogen-bearing vanadium alloy, which is in favor of cost reduction. The V/N ratio should be in the range of 4 to 6 in commercial production with the optimum ratio of 4.5.

Keywords-vanadium alloy; ferrovanadium; ferrovanadium nitride; V/N ratio

\section{INTRODUCTION}

As a strong carbide- and nitride-forming element, vanadium exists in the steel mainly in the form of vanadium carbide, nitride and/or carbonitride and solid solute. Therefore, the vanadium steel can be strengthened and toughened with grain refinement, precipitation and solid solution. It was reported that vanadium could be precipitated around the inclusions (like $\mathrm{MnS}$ ) in austenite, on the grain boundary, inside the grains and in ferrite including fibrous precipitation, interphase precipitation and random precipitation [1]. To enhance the improvement of yield strength with vanadium precipitation, the formation of vanadium carbonitride is preferred. This was because that [2] in the low- $\mathrm{N}$ vanadium steel (micro alloyed with ferrovanadium) a major portion of vanadium was dissolved in solid state in ferrite and only $36 \%$ is formed into vanadium nitride, but in the high-N one ( $\mathrm{V}-\mathrm{N}$ micro alloyed) $70 \%$ of vanadium is precipitated in the form of $\mathrm{V}(\mathrm{C}, \mathrm{N})$ which increases the contribution of $0.01 \% \mathrm{~V}$ to yield strength improvement from 5 - $10 \mathrm{MPa}$ up to approx. $25 \mathrm{MPa}$. Now the vanadium alloys used for steelmaking include FeV50, FeV80, $\mathrm{V}-\mathrm{N}, \mathrm{FeVN}, \mathrm{SiVN}$ [3], etc. In order to take full advantage of V$\mathrm{N}$ strengthening the nitrogen addition materials such as micro$\mathrm{N}$ alloy, $\mathrm{N}$-rich alloy, $\mathrm{SiN}, \mathrm{MnN}$ and $\mathrm{SiMnN}$ will be used. $\mathrm{FeV}$ should be used mainly in the steel with strict limits on nitrogen content, and V-N and FeVN would be preferred in the production of V-bearing high-strength hot rolled steel bars.

\section{CURRENT STATUS OF V-BEARING STEEL APPLICATION}

It can be seen from Fig. 1 that V-bearing steel is used almost equally in structural, special structural and tool steel

\author{
R.G. Bai, X.L. Zhang, H. Gao \\ Chengde Branch \\ Hebei Iron \& Steel Co., Ltd. \\ Chengde, China
}

with approx. one third of each in Germany; mainly in automobile steel for $50 \%$ as well as in pipe, tool and heat treated steel with $10 \%$ each in Japan; and in carbon, HSLA and alloy steel with approx. $30 \%$ of each in USA. In China it is mainly used in HSLA long and flat products with $63 \%$ in total and $27 \%$ in alloy steel with less usage in special steel compared to the developed countries. In average, the vanadium alloys usage worldwide is mainly in carbon, high strength, alloy and tool steel amounting up to $95 \%$ accumulatively. In 2013 the global vanadium production was 79534 tons, well balanced with the consumption of 79300 tons; while China produced 43 500 tons and consumed 35500 tons with extra supply of 8000 tons. The development of technologies like vanadium extraction from stone coal tends to increase further the overproduction.

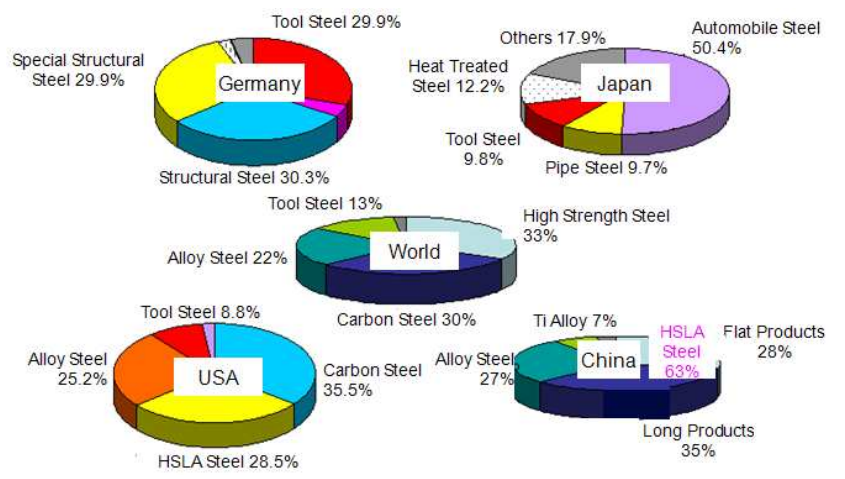

FIGURE I. APPLICATION OF V-BEARING STEEL IN DIFFERENT COUNTRIES.

As one of the leading companies for vanadium usage and high-strength bars production, Chenggang produces varieties of V-bearing steel, mainly HRB-series bar and wire rod and Q345BV-series hot rolled coil. It can be seen from Table 1 that the average specific consumption of vanadium in Chenggang was $0.2148 \mathrm{kgV} / \mathrm{T}$ of steel in 2012, and that for HRB400(E) was $0.3272 \mathrm{kgV} / \mathrm{T}$. The figures for Jan. - Jul. of 2013 were 0.2215 and 0.3172 , respectively, and the major portion of the V-bearing materials consumed was FeVN. Now the overall specific consumption of vanadium in Chenggang reaches 0.229 $\mathrm{kgV} / \mathrm{T}$, which is up to 6 times of that of the national average $(0.038 \mathrm{kgV} / \mathrm{T}), 2.6$ times of that of North America and 3 times of that of EU. 
TABLE I. VANADIUM CONSUMPTION BY CHENGGANG.

\begin{tabular}{|c|c|c|c|c|c|}
\hline Year & \multirow{3}{*}{2012} & \multicolumn{2}{|c|}{ Total Consumption } & \multicolumn{2}{c|}{ HRB400(E) Consumption } \\
\cline { 3 - 6 } & V-Alloy & $\begin{array}{c}\text { Consumption } \\
/ \mathrm{T}\end{array}$ & $\begin{array}{c}\text { Specific } \\
\text { Consumption } \\
/ \mathrm{kgV} / \mathrm{T}\end{array}$ & $\begin{array}{c}\text { Consumption } \\
/ \mathrm{T}\end{array}$ & $\begin{array}{c}\text { Specific } \\
\text { Consumption } \\
/ \mathrm{kgV} / \mathrm{T}\end{array}$ \\
\cline { 2 - 6 } & $\mathrm{FeV50}$ & 165.88 & 0.0268 & 146.16 & 0.0425 \\
\cline { 2 - 6 } & $\mathrm{FeVN}$ & 1163.66 & 0.188 & 979.098 & 0.2847 \\
\hline \multirow{2}{*}{$\begin{array}{c}\text { Jan. }- \\
\text { Jul. }\end{array}$} & FeV50 & 125.45 & 0.0278 & 98.82 & 0.053 \\
\cline { 2 - 6 } 2013 & $\mathrm{~V}-\mathrm{N}$ & 4.96 & 0.0011 & 3.73 & 0.002 \\
\cline { 2 - 6 } & FeVN & 869.14 & 0.1926 & 488.88 & 0.2622 \\
\hline
\end{tabular}

\section{CHARACTERISTICS OF VANADIUM ALLOYS}

As shown in Table 2, the nitrogen content of V-N Alloy as the first-generation $\mathrm{N}$-bearing vanadium alloy is limited within a certain range. However, the development of $\mathrm{V}-\mathrm{N}$ strengthening theory drives the N/V ratio up to $\geq 0.2$ for FeVN and even to 0.25 for the new SiVN alloy. To promote the precipitation strengthening the phase composition tends to transfer from $\mathrm{V}$ to $\mathrm{VCN}$ and $\mathrm{VN}$. Considering that the specific gravity of liquid slag is 3 , the specific gravity of vanadium alloys shall be higher than 3 in order to increase the absorption rate. The consumption of $\mathrm{FeVN}$ can be reduced when compared with V-N alloy. As a new product SiVN does not have enough data available for convincing statistics. Therefore, $\mathrm{SiVN}$ will need further investigation and tests before it can be widely accepted. Also its difference from combined alloying with V-N alloy and SiN shall be studied in detail. Now FeVN has been commonly used by the major steel producing provinces like Hebei, Shanxi, Liaoning and Shandong for cost saving; SiVN has been used by many mid-sized rebar producers in Panzhihua region. Shagang also increases SiVN usage, because the SiVN price is only approx. RMB 3000 higher than that of $\mathrm{FeV}$.

TABLE II. CHARACTERISTICS OF VANADIUM ALLOYS.

\begin{tabular}{|c|c|c|c|c|c|c|}
\hline & $\begin{array}{c}\text { N/V } \\
\text { Ratio }\end{array}$ & $\begin{array}{c}\text { Phase } \\
\text { Composition }\end{array}$ & $\begin{array}{c}\text { specific } \\
\text { gravity }\end{array}$ & $\begin{array}{c}\text { Melting } \\
\text { Temperatur } \\
\mathbf{e} \\
/{ }^{\circ} \mathrm{C}\end{array}$ & $\begin{array}{c}\text { V } \\
\text { Consumptio } \\
\text { n Saving }\end{array}$ & $\begin{array}{c}\text { V-N } \\
\text { combining } \\
\text { ratio }\end{array}$ \\
\hline $\mathrm{FeV}$ & - & $\mathrm{V}$ & $6.4-8.1$ & - & - & - \\
\hline $\begin{array}{c}\mathrm{V}-\mathrm{N} \\
\mathrm{Alloy}\end{array}$ & $\begin{array}{c}0.12- \\
0.23\end{array}$ & $\mathrm{VCN}$ & $\sim 3.0$ & $>2400$ & $20 \%-50 \%$ & $70 \%$ \\
\hline $\mathrm{FeVN}$ & $\geq 0.2$ & $\mathrm{VN}$ & $5.5-6.5$ & $<1650$ & $30 \%-60 \%$ & $90 \%$ \\
\hline $\mathrm{SiVN}$ & $\sim 0.25$ & $\mathrm{VN}, \mathrm{Si}_{3} \mathrm{~N}_{4}$ & $\sim 4.4$ & - & $\sim 38 \%$ & - \\
\hline
\end{tabular}

\section{EFFECT OF VANADIUM ALLOYS USE}

\section{A. Absorption rate of Vanadium Alloys}

As shown in Table 3, SiVN is added during refining to ensure the absorption rate, and the other V-bearing alloys are added during converter tapping with analysis tuning in refining. Without $\mathrm{N}$ addition, $\mathrm{FeV}$ is very suitable for the steel with strict limits on nitrogen content. SiVN will raise $\mathrm{Si}$ content and consequently reduce SiMn consumption and increase FeMn usage, which will change the production cost. Also the extra SiVN addition will influence the refining process. FeVN features higher $\mathrm{N}$ absorption rate than $\mathrm{V}-\mathrm{N}$ alloy, and there have no data available for SiVN. Chenggang has tested the FeVN addition during LF refining and found that $\mathrm{V}$ and $\mathrm{N}$ absorption rates can reach up to $95 \%$ and $60 \%$ respectively, but the extra addition amount would have influence on the refining process.

TABLE III. ADDITION OF VANADIUM ALLOYS AND ABSORPTION RATES.

\begin{tabular}{|c|c|c|c|c|}
\hline $\begin{array}{l}\text { Alloy } \\
\mathbf{S}\end{array}$ & $\begin{array}{l}\text { Addition } \\
\text { Means }\end{array}$ & Pros and Cons & $\begin{array}{c}\mathrm{V} \\
\text { Absorpti } \\
\text { on Rate } \\
/ \%\end{array}$ & $\begin{array}{c}\mathrm{N} \\
\text { Absorpti } \\
\text { on Rate } \\
/ \%\end{array}$ \\
\hline $\mathrm{FeV}$ & $\begin{array}{l}\text { Ar blowing } \\
\text { in ladle, } \\
\text { adding into } \\
\text { ladle when } \\
\text { tapping }\end{array}$ & $\begin{array}{l}\text { less inclusions, } \\
\text { stable V } \\
\text { absorption, no } \mathrm{N} \\
\text { addition }\end{array}$ & $\begin{array}{c}88.55- \\
89.87 \\
\text { Average: } \\
89.15\end{array}$ & - \\
\hline V-N & $\begin{array}{l}\text { Ar blowing } \\
\text { in ladle, } \\
\text { adding with } \\
\text { alloys when } \\
\text { tapping }\end{array}$ & $\begin{array}{l}\text { less inclusions, } \\
\text { stable V } \\
\text { absorption, } \\
\text { enhanced VN } \\
\text { effect }\end{array}$ & $\begin{array}{c}88.48- \\
89.13 \\
\text { Average: } \\
88.78\end{array}$ & $\begin{array}{c}30.27- \\
43.85 \\
\text { Average: } \\
35.62\end{array}$ \\
\hline FeVN & $\begin{array}{l}\text { Ar blowing } \\
\text { in ladle, } \\
\text { adding with } \\
\text { alloys when } \\
\text { tapping }\end{array}$ & $\begin{array}{l}\text { less inclusions, } \\
\text { stable V } \\
\text { absorption, } \\
\text { enhanced VN } \\
\text { effect }\end{array}$ & $\begin{array}{c}92.68- \\
93.23 \\
\text { Average: } \\
92.93\end{array}$ & $\begin{array}{c}38.16- \\
51.37 \\
\text { Average: } \\
44.28\end{array}$ \\
\hline SiVN & $\begin{array}{l}\text { Adding in LF } \\
\text { refining }\end{array}$ & $\begin{array}{l}\text { Si amount to be } \\
\text { controlled, extra } \\
\text { amount } \\
\text { influencing } \\
\text { refining process }\end{array}$ & $\begin{array}{c}\text { average: } \\
95\end{array}$ & - \\
\hline
\end{tabular}

\section{B. Influence of Vanadium Alloys on Steel Properties}

It can be seen from Table 4 that for similar yield strength the use of V-N alloy and FeVN leads a visible reduction of $\mathrm{V}$ content in the steel, and $\mathrm{N}$ addition refines further the grains due to grain growth inhibition by $\mathrm{V}(\mathrm{C}, \mathrm{N})$ and $\mathrm{VN}$ precipitation. Theoretically the FeVN (FeV55N12) consumption per ton of steel shall be 1.4 times (77/55) of that of V-N alloy (V77N16), but the actual figure in Chenggang is only 1.2 attributable to increased $\mathrm{N}$ content. As a new vanadium alloy, $\mathrm{SiVN}$ is less used yet. However, Linggang has made some tests and reported that it can meet the requirements for the production of HRB400E Ф25.

TABLE IV. DATA OF STEEL BARS PRODUCED USING DIFFERENT VANADIUM ALLOYS.

\begin{tabular}{|c|c|c|c|c|c|c|}
\hline Size & $\begin{array}{l}\text { Vanadiu } \\
\text { m Alloy }\end{array}$ & $\begin{array}{l}\mathrm{V} \\
/ \%\end{array}$ & $\begin{array}{l}\text { Grain } \\
\text { Size }\end{array}$ & $\begin{array}{c}\text { Rel } \\
\text { / MPa }\end{array}$ & $\begin{array}{l}\mathbf{R m} \\
/ \mathbf{M P a}\end{array}$ & $\begin{array}{c}\mathrm{Z} \\
/ \%\end{array}$ \\
\hline \multirow{4}{*}{$\begin{array}{c}\text { HRB40 } \\
0 \\
\text { Ф32 }\end{array}$} & FeV50 & 0.039 & 8.6 & 465 & 635 & 22 \\
\hline & V-N & 0.026 & 9.1 & 462 & 628 & 21 \\
\hline & $\mathrm{FeVN}$ & 0.024 & 9.3 & 465 & 630 & 20 \\
\hline & SiVN & - & - & \multicolumn{3}{|c|}{$\begin{array}{l}\text { Meeting requirements for } \\
\text { HRB400E } \Phi 25\end{array}$} \\
\hline
\end{tabular}




\section{Nitrogen Addition Processes}

To take full advantage of $\mathrm{V}-\mathrm{N}$ strengthening the nitrogen addition means such as VN, FeVN, SiVN, micro-N alloy, Nrich alloy, $\mathrm{SiN}, \mathrm{MnN}, \mathrm{SiMnN}$ and $\mathrm{N} 2$ bottom blowing have been applied. In Table 5 the nitrogen addition methods that Chenggang has used for the production of HRB400E Ф25 are summarized. It can be seen that the conventional FeV alloying results in the lowest $\mathrm{N}$ content and also the lowest yield strength. The nitrogen bottom blowing reaches the lowest operation cost and the highest $\mathrm{N}$ content, but the macroscopic examination shows that most of the subsurface blowholes in the billet are above Class 1, and the elongation at rupture is the lowest. On the basis of V-N alloy, the micro-N and N-rich alloys are also helpful for $\mathrm{N}$ increasing, and especially the micro-N one gets better results in addition to saving cost. The use of FeVN for HRB400E production enhances both V utilization and $\mathrm{N}$ increasing and ensures improvement of bar properties by V-N strengthening. The comprehensive analysis concludes that FeVN can be the major $\mathrm{V}$ micro alloying material for the production of V-bearing high-strength steel bars.

TABLE V. PROPERTIES OF HRB400E Ф25 PRODUCED WITH DIFFERENT ADDITION MEANS.

\begin{tabular}{|c|c|c|c|c|c|c|}
\hline \multirow{2}{*}{$\begin{array}{l}\text { N Addition } \\
\text { Means }\end{array}$} & \multirow{2}{*}{$\mathrm{N} / \%$} & \multirow{2}{*}{$\begin{array}{c}\text { Rel } \\
/ \\
\text { MPa }\end{array}$} & \multirow{2}{*}{$\begin{array}{c}\mathbf{R m} \\
/ \\
\mathbf{M P a}\end{array}$} & \multirow{2}{*}{$\begin{array}{c}\mathrm{A} \\
/ \%\end{array}$} & \multicolumn{2}{|c|}{ Impact Resistance } \\
\hline & & & & & $\mathrm{Rm} / \mathrm{Rel}$ & $\mathrm{Rm} / 400$ \\
\hline $\mathbf{F e V}$ & 0.0058 & 438 & 590 & 23 & 1.35 & 1.10 \\
\hline $\begin{array}{c}\mathrm{FeV}+\mathrm{N} 2 \\
\text { Bottom } \\
\text { Blowing } \\
\end{array}$ & 0.0157 & 455 & 605 & 19 & 1.33 & 1.14 \\
\hline V-N Alloy & 0.0100 & 450 & 605 & 20 & 1.34 & 1.13 \\
\hline FeVN & 0.0120 & 467 & 625 & 21 & 1.34 & 1.17 \\
\hline $\begin{array}{c}\text { V-N + } \\
\text { Micro-N } \\
\text { alloys }\end{array}$ & 0.0124 & 480 & 640 & 22 & 1.33 & 1.20 \\
\hline $\begin{array}{l}\mathrm{V}-\mathrm{N}+\mathrm{N}- \\
\text { Rich alloys }\end{array}$ & 0.0135 & 455 & 610 & 22 & 1.34 & 1.14 \\
\hline
\end{tabular}

\section{V/N ratio}

Fig. 2 shows the relationship between $\mathrm{V} / \mathrm{N}$ ratio and the measured vanadium precipitation, the theoretical vanadium precipitation and the theoretical combined nitrogen. It can be found that more nitrogen will be combined when the $\mathrm{V} / \mathrm{N}$ ratio increases, and this indicates that the reduction of free nitrogen weakens its negative aging effect. Both the measured and theoretical vanadium precipitations raise first and then decrease, which means the vanadium precipitation has a maximum value, i.e. $\mathrm{V}$ content has an optimum value at a certain $\mathrm{N}$ content. The deviation from this optimum value will lessen the improvement of mechanical properties. Therefore, it is recommended that for commercial production the $\mathrm{V} / \mathrm{N}$ ratio shall be controlled in the range of $4-6$ to maximize the $\mathrm{V}-\mathrm{N}$ strengthening. The optimum V/N ratio is 4.5, which is somehow different from the theoretical optimum value (3.64) reported by Yong Qilong, et al [4]. There has no nitrogen contained in $\mathrm{FeV}$, the $\mathrm{V} / \mathrm{N}$ ratio is 4 and 5 in FeVN and V-N, respectively, the original nitrogen content is typically $0.0040 \%-0.0070 \%$ in liquid steel, $\mathrm{N}$ bearing vanadium alloys feature different and varying $\mathrm{V}$ and $\mathrm{N}$ absorption rates and so on, such conditions result in discrepancies between $\mathrm{V} / \mathrm{N}$ ratio of vanadium alloys and that of the steel and influence the V-N strengthening. Therefore, it is insufficient to ensure the $\mathrm{V} / \mathrm{N}$ ratio and steel properties only by the addition of vanadium alloys. To reach the optimum V/N ratio (4.5) Chenggang developed different combined Valloying processes such as $\mathrm{FeV}$ with $\mathrm{FeVN}$ and $\mathrm{FeVN}$ with micro-N alloy.

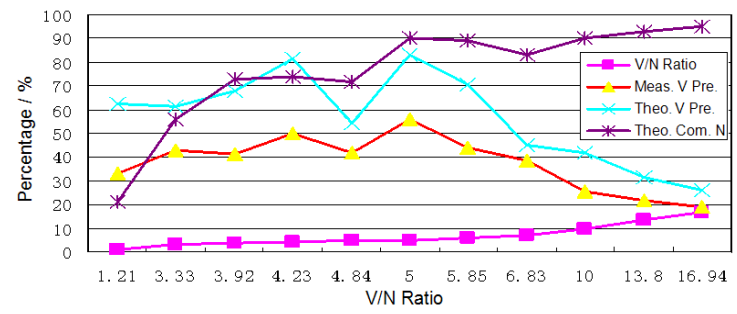

FIGURE II. PRECIPITATION BEHAVIOURS AT DIFFERENT V/N RATIO.

In order to better analyze the precipitation behaviour of $\mathrm{V}(\mathrm{C}, \mathrm{N})$ in vanadium bearing steel, $\mathrm{V}(\mathrm{C}, \mathrm{N})$ start precipitation temperature was simulated on the same carbon content $(0.235 \% \mathrm{wt})$ and different content of vanadium and nitrogen. Some trends could be obtained from $\mathrm{V}(\mathrm{C}, \mathrm{N})$ start precipitation temperature curves showed in Fig.3, the $\mathrm{V}(\mathrm{C}, \mathrm{N})$ start precipitation temperature gradually decreased with lowering vanadium content and the $\mathrm{V}(\mathrm{C}, \mathrm{N})$ start precipitation temperature gradually increased with increasing of nitrogen content for the same carbon content. the $\mathrm{V}(\mathrm{C}, \mathrm{N})$ start precipitation temperature in the low- $\mathrm{N}$ vanadium steel was below $1000^{\circ} \mathrm{C}$ even the vanadium content up to $0.12 \% \mathrm{wt}$, the $\mathrm{V}(\mathrm{C}, \mathrm{N})$ start precipitation temperature rise to $1000^{\circ} \mathrm{C}$ only when the vanadium content increased to $0.032 \%$ wt for high-N vanadium steel with the $0.02 \%$ wt nitrogen content. Therefore, the precipitation strengthening effect could be rapidly enhancing by increasing nitrogen content of vanadium bearing steel. Adding nitrogen promoted the precipitation of $1-10 \mathrm{~nm}$ nanoscale NV also reported by Shuping Liu et al [5].

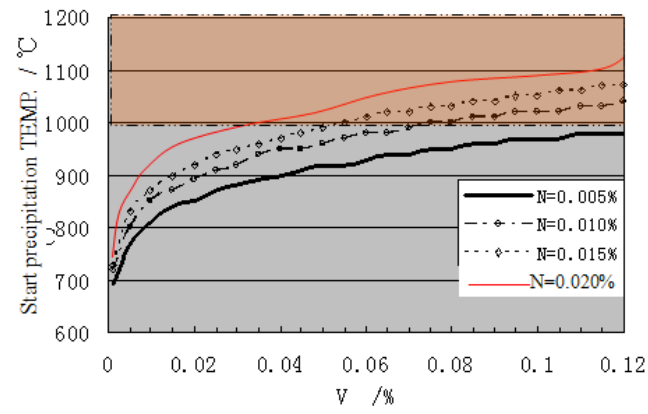

FIGURE III. START PRECIPITATION TEMP CURVES OF V(C, N).

\section{CONCLUSIONS}

[1] FeV shall be used mainly in the steel with strict limits on nitrogen content. N-bearing vanadium alloys can enhance V-N strengthening and reduce cost.

[2] FeVN can be the major vanadium alloy for V-N strengthening. Although having cost advantages, SiVN will need further investigation and tests before it can be widely accepted.

[3] For commercial production the $\mathrm{V} / \mathrm{N}$ ratio shall be controlled in the range of 4 - 6 to maximize the $\mathrm{V}-\mathrm{N}$ strengthening. The optimum $\mathrm{V} / \mathrm{N}$ ratio is 4.5. The $\mathrm{V} / \mathrm{N}$ ratio can be ensured with combined V-alloying processes according to existing production conditions. 
[4] References

[5] Yang, C.F., Zhang, Y.Q., Wang, R.Z., Vanadium Steel Metallurgical Principle and Application, Metallurgical Industry Press: Beijing, pp.5161, 2012.

[6] Yang, C.F. \& Zhang, Y.Q., Applications of V - N microalloying technology in HSLA steels, Iron and Steel, 37(11), pp.42-47, 2002.

[7] Zhang, G.D., Lei, W.H., Tan, G.C., et al., Synthesization and application of new microalloy SiVN, China Hi-tech Enterprises, (26), pp. 8-10, 2012.

[8] Yong, Q.L., Liu, Z.D., Sun, X.J., et al., Calculation and analysis of solid solubility and chemical composition of vanadium carbonitride in microalloyed vanadium steel, Iron Steel Vanadium Titanium, 26(2), pp. 20-24, 2005.

[9] Liu, S.P., Yang, C.F., Zhang, Y.Q., Effect of nitrogen on property and pricipitation phase in vanadium steel, Heat Treatment of Metals, 26(10), pp.7-9, 2001. 